\title{
TENANT PPK UMN AL WASHLIYAH DALAM MENGEMBANGAN KEWIRAUSAHAAN
}

\author{
Siti Fatima Hanum ${ }^{1}$, Shita Tiara ${ }^{2}$, Samran $^{3}$ \\ Universitas Muslim Nusantara Al Washliyah \\ Kampus A. Jl. Garu II No. 93 Medan \\ hanum_farmasi@yahoo.com
}

\begin{abstract}
ABSTRAK
Perguruan tinggi memiliki peran untuk memotivasi para mahasiswa dan sarjananya menjadi young entrepreneurs dan merupakan bagian dari salah satu faktor pendorong pertumbuhan kewirausahaan. Tujuan kegiatan Program Pengembangan Kewirausahaan (PPK) di Universitas Muslim Nusantara (UMN) Al Washliyah untuk menghasilkan wirausaha yang mandiri berbasis iptek dan siap beraktivitas di masyarakat. Metode pendekatan pada program PPK secara Participatory Action Learning System (PALS). Adapun tenant PPK UMN Al Washliyah adalah mahasiswa dan Alumni UMN Al Washliyah. Kegiatan Program Pengembangan Kewirausahaan dengan memberikan bimbingan, motivasi, pelatihan, pendampingan, dan konsultasi kewirausahaan.Kegiatan PPK UMN Al Washliyah telah melakukan kegiatan antara lain, yaitu memperkenalkan tentang kewirausahaan dan memotivasi mahasiswa untuk berwirausaha pada kegiatan kuliah umum kewirausahaan islami, melakukan rekrutmen tenant peserta PPK UMN Al Washliyah, pelatihan kewirausahaan, peningkatan keterampilan berwirausahaan dengan magang, praktek dan kunjungan ke tempat usaha, memberikan modal usaha berupa peralatan penunjang dan bahan habis pakai, pameran produk, dan evaluasi kegiatan kerja tenant. Kegiatan PPK UMN Al Washliyah pada tahun pertama ini telah menghasilkan 5 (lima) orang wirausaha mandiri dan 15 (lima belas) orang sedang merintis berwirausaha.
\end{abstract}

Kata kunci : pengembangan kewirausahaan, wirausaha baru, kerjasama

\begin{abstract}
Higher education has a role to motivate students and undergraduates to become young entrepreneurs and are part of one of the factors driving the growth of entrepreneurship. The purpose of the Entrepreneurship Development Program (PPK) is at the Muslim Nusantara University (UMN) Al Washliyah to produce independent science-based entrepreneurs and are ready to be active in the community. Approach method in the PPK program by Participatory Action Learning System (PALS). The PPN UMN Al Washliyah tenants were UMN Al Washliyah students and Alumni. Entrepreneurship Development Program Activities by providing guidance, motivation, training, mentoring, and entrepreneurship consultations. The activities of PPK UMN Al Washliyah have carried out activities including introducing entrepreneurship and motivating students to entrepreneurship in Islamic entrepreneurship general lecture activities, recruiting KDP participants. UMN Al Washliyah, entrepreneurship training, improving entrepreneurship skills with apprenticeships, practices and business visits, providing business capital in the form of supporting equipment and consumables, product exhibitions, and evaluating tenant work activities. The activity of PPK UMN Al Washliyah in this first year had produced 5 (five) independent entrepreneurs and 15 (fifteen) people were pioneering entrepreneurship.
\end{abstract}

Keywords: entrepreneurship development, new entrepreneurship, cooperation 


\section{PENDAHULUAN}

\subsection{LATAR BELAKANG}

Universitas Muslim Nusantara (UMN) Al Washliyah merupakan lembaga Pendidikan Tinggi dibawah naungan Organisasi Kemasyarakatan Islam Al Jami'yatul Washliyah yang selain mempunyai tanggung jawab dibidang pendidikan juga bidang lainnya seperti misi da'wah, amal sosial, pemberdayaan aset dan pemberdayaan ekonomi umat.

Berdasarkan perubahan kurikulum pada tahun akademik 2013/2014 mengacu pada kurikulum Kerangka Kualifikasi Nasional Indonesia (KKNI), UMN Al Washliyah dalam melaksanakan tri darma perguruan tinggi melakukan perubahan dalam peningkatan capaian pembelajaran (learning outcomes), agar menghasilkan sumber daya manusia yang bermutu dan produktif. Untuk menghasilkan sumber daya manusia yang bermutu dan produktif maka setiap fakultas di UMN Al Washliyah menawarkan mata kuliah wajib yang harus diperoleh mahasiswa untuk meningkatkan keterampilan seperti mata kuliah magang pada FKIP, Fakultas Sastra, Fakultas Hukum dan Fakultas Ekonomi, mata kuliah Kewirausahaan (entrepreneur) pada FMIPA, Fakultas Ekonomi dan Fakultas Pertanian.

Perguruan tinggi memiliki peran untuk memotivasi para mahasiswa dan sarjananya menjadi young entrepreneurs dan merupakan bagian dari salah satu faktor pendorong pertumbuhan kewirausahaan (Agustina, 2015). Kewirausahaan kata kunci kemajuan suatu bangsa karena kewirausahaan memberikan ruang yang luas bagi inovasi yang dapat menciptakan nilai tambah ekonomi yang cukup besar. Setelah menyelesaikan study, bahkan masih sebagai mahasiswa harus dapat mengembangkan talentanya untuk menjadi seorang entrepreneur yang handal (Sampurno, 2010).

Antusias mahasiswa UMN Al Washliyah dalam kegiatan berwirausaha terus mengalami peningkatan. Wirausaha yang dilakukan baik secara mandiri maupun kelompok. Mahasiswa juga aktif mengikuti program dari Kemenristek Dikti yaitu Program Kreatifitas Mahasiswa (PKM). Pada tahun 2017 mahasiswa UMN Al Washliyah yang lulus didanai oleh Kementerian Riset, Teknologi dan Pendidikan Tinggi Direktorat Jenderal Pembelajaran dan Kemahasiswaan berjumlah 6 orang dan tahun 2018 yang lulus berjumlah 4 orang.

\subsection{Tujuan}

Adapun tujuan pada Program Pengembangan Kewirausahaan (PPK) di Universitas Muslim Nusantara Al Washliyah, adalah:

1. Menciptakan wirausaha berbasis iptek yang siap berkreativitas di masyarakat.

2. Meningkatkan keterampilan manajemen usaha pada tenant PPK UMN Al Washliyah.

3. Memberikan pembinaan $\mathrm{dn}$ pelatihan berupa praktek dan magang pada tenant PPK UMN Al Washliyah.

4. Menciptakan lapangan kerja bagi tenant.

5. Menjalin kerjasama dengan lembaga atau usaha lain untuk pengembangan usaha tenant.

\subsection{Pendekatan Pemecahan Masalah}

Kegiatan kewirausahaan yang dilakukan mahasiswa masih banyak mengalami hambatan yaitu masih 
lemahnya kemampuan dan keterampilan berwirausaha, masih lemahnya dalam pemodalan, belum mampu mengakses pasar dan belum mampu mengakses dengan teknologi. Melalui program PPK diharapkan dapat membantu mengembangkan kewirausahaan melalui peningkatan keterampilan berwirausaha, konsultan bisnis, pendampingan, pembinaan kegiatan usaha, menyediakan kebutuhan yang diperlukan mahasiswa berupa peralatan penunjang produksi, perluasan jaringan pemasaran dan jaringan kerjasama dengan pihak pemerintah maupun swasta.

\section{METODE PELAKSANAAN}

Pelaksanaan Program

Pengembangan Kewirausahaan (PPK) UMN Al Washliyah dengan metode pendekatan PALS (Participatory Action Learning System). Untuk perekrutmen tenant dilaksanakan dengan langka-langka sebagai berikut:

1. Rekrutmen tenant peserta Program Pengembangan Kewirausahaan (PPK) di Universitas Muslim Nusantara Al Washliyah dilakukan secara bertahap. Pengrekrutan tenant peserta PPK berkoordinasi dengan unit bidang kemahasiswaan.

2. Melakukan seleksi (recrutment test) yaitu test kewirausahaan (enterpreneurship test) dan test kepribadian (personality test).

3. Tenant dinyatakan yang lulus jika nilai melebihi skor passing grade kemudian melanjutkan program entrepreneurship capacity building, yaitu:

1) mengikuti diklat program pengembangan kewirausahaan.

2) mengikuti magang kewirausahaan.
3) menjadi inkubator kewirausahan.

4. Proses pelaksanaan kegiatan program PPK di UMN Al Washliyah, dilakukan dengan beberapa tahap, yaitu:

1) Tahap Pembelajaran

2) Tenant diberikan pembelajaran yang difokuskan pada upaya pemahaman tenant terhadap masalah, realitas dan kendalakendalan yang dihadapi dalam berwirausaha dengan memberikan contoh kasuskasus yang terjadi baik dari aspek hukum, aspek pasar dan pemasaran, aspek keuangan, aspek teknik atau operasi, aspek manajemen dan organisasi maupun aspek dampak lingkungan.

3) Mengevaluasi kegiatan pembelajaran kewirausahaan tenant dengan tujuan untuk mengetahui umpan balik (feedback) kegiatan program apa sudah tercapai. Evaluasi tenant dilakukan dengan cara test tertulis dan wawancara.

4) Tenant yang belum mempunyai pengalaman dalam berwirausaha atau belum memiliki usaha maka akan diberikan pelatihan penyusunan rencana bisnis (Bussines Plan).

\section{HASIL DAN PEMBAHASAN}

Kegiatan Program

Pengembangan Kewirausahaan (PPK)

Universitas Muslim Nusantara

(UMN) Al Washliyah telah dilaksanakan dengan melibatkan mahasiswa dan alumni sebagai tenant. Kegiatan rekrutmen tenant dilakukan di Kampus Abdul Rahman Syihab Aula OK Usman. Untuk mensosialisasikan kegiatan perekrutan tenant dilakukan secara 
langsung dan tidak langsung kepada mahasiswa maupun alumni dengan menyampaikan langsung ke civitas akademik UMN Al Washliyah melalui Dekan, Wakil Dekan III, Ketua Program Studi, mahasiswa dan alumni, serta memberikan pengumuman melalui spanduk yang ditempel pada tempat yang strategis di lingkungan UMN Al Washliyah dan juga melalui media online.

Calon tenant yang lulus pada pendaftaran maka selanjutnya mengikuti test kewirausahaan. Test kewirausahaan dilakukan dengan membagi beberapa kelompok dari peserta calon tenant sesuai dengan bidang wirausahaanya. Kemudian setiap kelompok menyampaikan ide bisnisnya yang akan dilakukan. Kegiatan ini dibimbing oleh tim PPK UMN Al Washliyah, tim memberikan arahan dan bimbingan terhadap minat, bakat dan pengetahuan kewirausahaan kepada calon tenant.

Pelaksanaan magang ke perusahaan mitra pada kegiataan PPK UMN Al Washliyah tahun 2018 dilakukan pada perusahaan PT. Kimia Farma Apotek Cabang Medan dan perusahaan roti Cirasa Bakery. Selama magang tenant berstatus traning di perusahaan mitra. Kegiatan magang ini diharapkan dapat menambah pengalaman tenant yang berwirausaha dalam bidang makanan tentang proses produksi baik secara kualitas maupun kuantitas produksi, peralatan dan teknologi yang digunakan, strategi pemasaran, dan kendala-kendala yang dihadapi dan cara-cara untuk menyelesaikan permasalahan yang timbul. Setelah mengikuti magang tenant membuat laporan hasil kegiatan magang. Laporan tersebut kemudian dievaluasi oleh dosen pendamping magang yang merupakan juga tim PPK UMN Al
Washliyah. Selama pelaksanaan magang tenant diberikan transportasi dan konsumsi. Pola kegiatan magang ini disebut dengan pola Learning by Doing.

Upaya untuk meningkatkan usaha yang dilakukan tenant tim PPK UMN Al Washliyah memberikan bantuan berupa peralatan dan bahan habis pakai kepada tenant. Pemberian bantuan diberikan kepada tenant yang sedang merintis usaha baru dan tenant yang telah memiliki usaha.

Kegiatan PPK UMN Al Washliyah menghasilkan 5 (lima) wirausaha mandiri berbasis Iptek dengan jenis usaha produk dan jasa, yaitu: 1) Foot Salt Aromatic, 2) Smok Tas dan Selimut HP, 3) Candle Relaksasi 4) Minuman kesehatan Misekunas, 5) Jahe Instant, 6) Kripik Kulit Buah Naga, 7) Bouget Bunga dan Boneka Flanel, 8) Apotek Anugerah, 9) Apotek Sabadolok dan 10) Photografi.

\section{KESIMPULAN}

Kegiatan pengabdian kepada masyarakat program PPK UMN Al Washliyah telah melakukan perekrutan tenant sebanyak 23 (dua puluh tiga) tenant dengan bidang usaha produk dan jasa usaha. Tenant telah melakukan kegiatan magang di Industri Roti Cirasa Bakery dan PT. Kimia Farma Apotek Cabang Medan. Terbentuknya 5 tenant wirausaha mandiri berbasis Iptek. PPK UMN Al Washliyah telah melakukan kerjasama dengan lembaga atau mitra usaha dengan pendampingan dari UMN Al Washliyah.

\section{DAFTAR PUSTAKA}

Agustina T.S, 2015, Kewirausahaan, teori dan penerapan pada wirausaha dan UKM di 
Indonesia, Jakarta, Mitra

Wacana Media.

LP2M, 2016, Rencana Startegi

(Renstra) Program

Pengabdian Pada Masyarakat (PPM) 2016-2020,

Universitas Muslim

Nusantara Al Washliyah

Sampurno. (2010). Manajemen

Farmasi. Cetakkan

Pertama. Yogyakarta.

Mahenoko.

Satiyadnya, N, dkk, 2013, Ipteks Bagi

Kewirausahaan (IbK) di

Universitas Pendidikan

Ganesha (UNDIKSHA),

Fakultas Teknik dan

Kejuruan, Lembaga

Pengabdian Kepada

Masyarakat, Laporan

Pengabdian Kepada

Masyarakat Ipteks Bagi

Kewirausahaan (IbK)

Sutrisno, E. (2010). Manajemen Sumber Daya Manusia. Edisi

Pertama. Cetakan ke - 2.

Jakarta. Kencana.

UMN Al Washliyah, 2014, Buku Pedoman Akademik. 